\title{
MANITOBA BLACK GUILLEMOT SPECIMEN
}

\author{
by Robert W. Nero, Manitoba Museum of Man and Nature
}

147 James Ave., Winnipeg 2, Manitoba

An adult bird in winter plumage found dead on November 12, 1966 on the bank of the Red River at Morris, 33 miles south of Winnipeg, comprises the first specimen of the Black Guillemot (Cepphus grylle) for Manitoba. Identification of the specimen was confirmed by W. Earl Godfrey, National Museum of Canada, who determined it to be C. $g$. ultimus, the expected subspecies for the Hudson Bay area (pers. corres., December 8, 1967). For this interesting record we are indebted to Mr. Michael Dixon of Morris, who discovered the dead bird, and Charles Dixon, Wildlife Branch, Manitoba Department of Mines and Natural Resources, who brought the refrigerated bird to the museum on April 20, 1967. Judging by the condition of the soft parts of the bird it had been found probably shortly after death. Although the stomach contents were nil there was still sorne fat on the major feather tracts, which suggests that the bird perished from exhaustion rather than

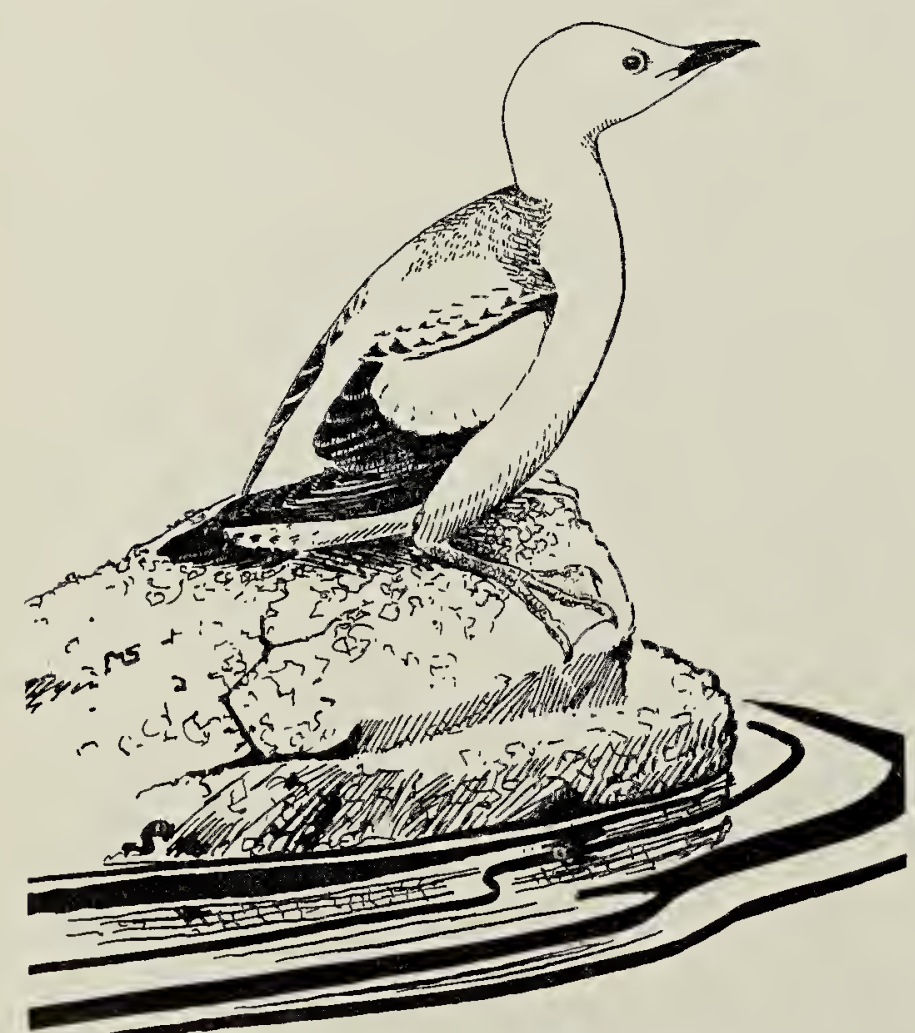

Black Guillemot, winter plumage,

Morris, Manitoba, November 12, 1966 starvation. The specimen is of undetermined sex (MMMN 1.2-2447).

Godfrey (1966) describes the Black Guillemot as a "teal-sized sea-diver with slender pointed bill and large white wing patch"; in the breeding plumage it is black all over, with the exception of the wing patch. The specimen from Morris is nearly all white, with black wings and tail and some dark flecking on the upper back (see figure). Godfrey notes that this species breeds in eastern arctic Canada, south along the east side of Hudson Bay to James Bay, but is not generally found along the west side of Hudson Bay. It winters in open waters off the breeding grounds, including Hudson Bay.

The present specimen record is of special interest inasmuch as the Black Guillemot seldom strays inland. Godfrey (op. cit.) lists it as accidental in Canada only for southern Ontario ("Toronto; sight record for Kingston"); the A.O.U. Check-list (1957) records it as accidental only in eastern Pennsylvania; there seem to be no other inland records. In contrast, some other sea birds of the family Alcidae are frequently found inland. The Ancient Murrelet (Synthliboramphus antiquus), for example, has been reported from at least 27 localities in the United States and Canada (Munyer, 1965), although its breeding range is limited to coastal islands of the North Pacific (Godfrey, op. cit.). Munyer relates these records, of which two-thirds are dated November or late Octaber, to weather disturbances over the Pacific coast. A Manitoba Ancient Murrelet specimen, with an unusually early fall date, was unfortunately overlooked by Munyer: one was found alive on a Winnipeg street on October 8, 1953 (MMMN 1.2-2252).

Weather records for the week preceding the occurrence of the Black 
Guillemot specimen at Morris indicate that subsequent to November 8 there were no conditions which could be assumed to have caused a southwestward flight from Hudson Bay to southern Manitoba. Between November 5 and 8, however, an intense storm moving north along the east side of Hudson Bay caused a strong southwestwardly flow of moist air over the bay. On November 5 , winds up to 35 $\mathrm{mph}$ from the north were recorded at Hudson Bay. On the previous day, winds in the same area were northeast up to $35 \mathrm{mph}$. In southern Manitoba in early November freeze-up is still not complete. The large lakes of central Manitoba - Lakes Winnipeg, and Winnipegosis - still have extensive ice-free areas, as do the major rivers of the eastern part of the province.

Preble's sight record of a Black Guillemot (earlier known as Mandt or Mandt's Guillemot) on Button Bay at Churchill on August 19, 1900 (1902: 77 ) is apparently the first record of this species for Manitoba. At Churchill, Taverner and Sutton (1934: 59) recorded five seen off Eskimo Point on August 6, 1930, and one seen on July 15,1933 . Ornithologists working recently at Churchill observed this species on two occasions in the same year as that of the present specimen: John Lamey recorded a flock of 12 seen on June 28, 1966 off Cape Merry (pers. corres. January 24, 1967); Joseph R. Jehl, Jr., reports seeing one flying along the coast at Churchill on July 22, 1966 (pers. corres., December $29,1967)$. Jehl notes that the timing of the several Churchill records suggests that the birds were postbreeding.

There seem to be no other valid records for Manitoba. Thompson (1891:468) only guessed that they might occur here, stating: "Recorded by Andrew Murray, from Severn House [Ontario], and therefore probably Manitoban." The Manitoba Museum has records of two mounted specimens said to have been taken in 1916 in Albany (Ontario) or at Chur- chill. In the absence of more precise information these are hardly acceptable as evidence. No Manitoba records are given by Manning (1952), the A.O.U. Check-list (1957), or Godfrey (1966). The status of the Black Guillemot in Manitoba is thus accidental inland though it is a casual visitant in late summer along the northern seacoast.

I am grateful to Harold Hosford and Richard Sutton for assistance in the preparation of this report.

\section{LITERATURE CITED}

American Ornithologists' Union Committee. 1957. Check-list of North American birds. Fifth ed., Baltimore, Md. 691 pp.

Godfrey, W. E. 1966. The birds of Canada. Nat'l Mus. Can. Bull. No. 203, Biol. Series No. 73. Ottawa. 428 pp., 69 color plates, 71 line drawings, 2 maps.

Manning, T. H. 1952. Birds of the west James Bay and southern Hudson Bay coasts. Nat'l Mus. Can. Bull. No. 125, Biol. Series No. 43. 114 pp., with 7 plates.

Munyer, E. A. 1965. Inland wanderings of the Ancient Murrelet. Wilson Bull., 77:235-242.

Preble, E. A. 1902. A biological investigation of the Hudson Bay region. U.S. Bur. Biol. Surv., N. Amer. Fauna No. 22. 140 pp.

Taverner, P. A., and G. M. Sutton. 1934. The birds of Churchill, Manitoba. Annals Carnegie Mus., Vol. 23, pp. 1-83, plus 14 plates.

Thompson, E. E. $(=$ E. T. Seton $)$. 1891. The birds of Manitoba. Proc. U.S. Nat'l Mus. Vol. 13, 1890, pp. 457-643, Washington.

\section{RECORDS OF INDIGO BUNTING WANTED}

Martin MeNicholl is preparing a report on the status of the Indigo Bunting in Saskatchewan and Manitoba, and would appreciate receiving records of its occurrence in this area. Please send records to

Martin McNicholl

1281 Valour Road, Winnipeg, Man.

\section{CO-OPERATIVE SPRING MIGRATION STUDY}

Records are again requested for the continent-wide survey being made under the auspices of the U.S. Fish and Wildlife Service. As soon as it is available, the list of species for which reports are wanted can be obtained from Mrs. Mary Houston. Please submit your records to her by June 15, 1968 at 863 University Drive, Saskatoon. 